\title{
PERAN SIKAP KONSUMEN DALAM MEMEDIASI PENGARUH RELIGIUSITAS DAN REPUTASI MEREK TERHADAP MINAT BELI ULANG
}

\author{
Ken Sudarti \\ Salim Bakhrul Ulum \\ Universitas Islam Sultan Agung Semarang \\ kensudarti@unissula.ac.id
}

\begin{abstract}
This research is brainstormed by the franchise business which develops rapidly. There are so many franchise trade marks which are developed in Indonesia especially in Semarang such as Kentucky Fried Chicken (KFC). McDonald, Pizza Hut, Hoka-Hoka Bento, etc. As a fast food restaurant, KFC has so many competitors which always compete to satisfy the costumers. In order to attract the customers, KFC has to improve the quality of taste, services and product innovations. It is done in order to keep the reputations of its trade mark and improve the repurchase intention. Based on the phenomenon above, the research focuses to analyze how to improve the repurchase intention of KFC product in Semarang based on religiosity, reputation of trade mark and the customers attitude. The object of the research are the customers of KFC in Semarang city which involves 100 responders. The sampling technique used in this research is purposive sampling. It is a sampling technique based on current criteria. The data collecting uses questioners which opened questions and closed questions. The data analysis uses double regresi linier and sobel test with SPSS. The result of the analysis shows that the religiosity and reputation of trade mark has a positive and significant impact on repurchase intention.
\end{abstract}

Keywords : Religiosity, Reputation Of Trade Mark, Customer Attitude and Repurchase Intention.

\section{PENDAHULUAN}

Perkembangan bisnis khususnya waralaba (franchise) kini semakin berkembang di Indonesia, terbukti dengan banyaknya jumlah perusahaan franchise yang berdiri hampir disetiap daerah sehingga semakin menarik minat beli konsumen. Ketertarikan masyarakat Indonesia terhadap peluang usaha waralaba relatif tinggi. Bisnis waralaba di Indonesia dimulai pada tahun 1970 ditandai dengan munculnya beberapa restoran cepat saji (fast food). Pada awal tahun 90-ann hanya terdapat sekitar 35 merek waralaba, setelah itu pada tahun 2008 melonjak hingga 700 merek yang telah diwaralabakan. Waralaba yang berkembang di Indonesia antara lain : Kentucky Fried
Chicken, McDonald's, Pizza Hut, HokaHoka Bento dan masih banyak lagi.

Masyarakat di kota Semarang mayoritas adalah beragama Islam sehingga berpedoman bahwa semua makanan dan minuman yang dikonsumsi harus halal (baik itu dari cara mendapatkannya atau proses pengolahannya). Menurut mereka, saat ini halal bukan lagi menjadi gaya hidup, tetapi adalah kebutuhan semua konsumen terutama bagi mereka yang beragama Islam. Religiusitas seseorang diwujudkan dalam sisi kehidupannya, bukan hanya ketika seseorang melakukan ritual ibadah saja tetapi ketika melakukan aktivitas lain yang didorong oleh kekuatan spiritual. Berdasarkan sikap ini maka seseorang 
dalam melakukan suatu aktivitas sesuai dengan ketentuan agama, sesuai dengan perintah Tuhannya dengan tujuan mendapat keridhaan-Nya. Karenanya faktor agama adalah salah satu motivator penting untuk mendorong minat untuk membeli makanan dan minuman yang ingin mereka konsumsi. Para konsumen memilih makanan yang ingin mereka konsumsi sesuai dengan keyakinan mereka.

\section{KAJIAN PUSTAKA Minat Beli Ulang}

Menurut Peter dan Olson (2010) minat adalah sebuah rencana untuk terlibat dalam suatu perilaku khusus untuk mencapai tujuan. Sedangkan menurut

Schiffman dan Kanuk (2007) minat beli adalah sesuatu kekuatan psikologis yang ada didalam diri individu yang berdampak dilakukannya sebuah tindakan.

Menurut Kotler (2007) minat beli ulang merupakan minat pembelian yang didasarkan atas pengalaman pembelian yang telah dilakukan dimasa lalu, minat beli ulang mencerminkan tingkat kepuasan yang tinggi dari konsumen dalam mengkonsumsi suatu produk. Keputusan untuk membeli ulang atau tidak membeli ulang suatu produk timbul setelah konsumen mencoba suatu produk, kemudian timbul rasa suka atau tidak suka terhadap produk tersebut. Konsumen yang puas akan barang atau jasa yang telah dibelinya, akan berfikir untuk melakukan pembelian kembali terhadap barang atau jasa yang bersangkutan.

\section{Sikap Konsumen}

Istilah sikap berasal dari kata latin yang berarti "Posthure" atau "posisi fisik". Pengertian umum bahwa sikap adalah posisi fisik yang dapat menunjukkan berbagai jenis tindakan, dimana seseorang akan melaksanakannya. Sikap adalah kecenderungan belajar untuk berperilaku dengan cara yang konsisten sehubungan dengan objek tertentu (Schiffman dan Kanuk, 2010). Menurut Fishbein dan Ajzen
(2004) sikap merupakan ekspresi perasaan yang mencerminkan perasaan senang atau tidak senang terhadap suatu objek.

Robbins (2006) mengemukakan sikap adalah pernyataan-pernyataan atau penilaian evaluativ berkaitan dengan objek, orang atau suatu peristiwa. Selain itu sikap juga dipandang sebagai predikator yang efektif untuk mengetahui perilaku konsumen (Suryani, 2008). Kemudian menurut Schiffman dan Kanuk (2010) sikap adalah ekspresi perasaan yang berasal dari dalam diri individu yang menggambarkan apakah seseorang senang atau tidak senang, suka atau tidak suka terhadap suatu objek tertentu. Sikap adalah evaluasi, perasaan dan kecenderungan seseorang yang relatif konsisten terhadap suatu objek atau gagasan, sikap juga dapat menempatkan seseorang kedalam satu pikiran, untuk bergerak mendekati atau menjahui sesuatu (Kotler dan Amstrong, 2005).

\section{Religiusitas}

Dalam studi keagamaan sering dibedakan antara kata religion dengan kata religiusitas. Religiusitas lebih mengarah pada kualitas penghayatan dan sikap hidup seseorang berdasarkan nilai-nilai keagamaan yang diyakininya, jadi lebih menekankan pada subtansi nilai-nilai luhur keagamaan. Religi berasal dari kata religion sebagai bentuk dari kata benda yang berarti agama atau kepercayaan akan adanya sesuatu kekuatan kodrati diatas manusia. Religiusitas berasal dari kata religiosity yang berarti keshalihan, pengabdian yang besar terhadap agama. Religiusitas erat kaitannya pada kepercayaan dengan nilai-nilai agama serta identik akan jiwa spiritiual (religi) yang melekat pada diri seseorang. Normanorma religius yang sudah diterima dan dipelajari kemudian diimplementasikan pada kehidupan sehari-hari akan menciptakan pola yang konsrtuktif pada diri seseorang.

Religiusitas didefinisikan sejauh mana seseorang individu berkomitmen untuk mempelajari dan mengamalkan nilai-nilai 
agama serta ajaran- ajarannya (Abd Rahman et al, 2015). Nashori dan Mucharam (2002) menjelaskan religiusitas adalah seberapa jauh pengetahuan seseorang tentang agama, seberapa kokoh keyakinan terhadap agama, seberapa tekun pelaksanaan ibadah dan akidah serta seberapa dalam pengahayatan atas agama yang dianutnya. Sedangkan Hardjana (2005) menyatakan religiusitas merupakan suatu perasaan dan kesadaran interaksi antara individu dengan Sang Pencipta.

\section{Reputasi Merek}

Menurut Kotler (2005) merek merupakan janji penjual untuk memberikan tampilan, manfaat dan jasa tertentu pada pembeli. Sementara definisi merek menurut American Marketing Association (AMA) dalam buku The Power of Brand, merek adalah nama, istilah, tanda, simbol, atau rancangan, bahkan kombinasi dari semua hal-hal tersebut, yang digunakan oleh perusahaan untuk memudahkan konsumen untuk membedakan suatu produk dengan produk lainnya.

Menurut Shimp et al (2000) dalam Sangadji dan Sopiah (2013) reputasi merek merupakan jenis persepsi yang muncul dibenak konsumen ketika ingat dengan merek tertentu. Sedangkan Kertajaya (2005) mengatakan bahwa reputasi merek adalah persepsi dari seluruh asosiasi yang terkait dari suatu merek yang tertanam dibenak konsumen. Pembentukan reputasi merek juga dipengaruhi oleh pengalaman konsumen. Sedangkan menurut Kotler (2005) citra merek adalah sejumlah keyakinan tentang suatu merek.

\section{Pengaruh Religiusitas Terhadap Minat Beli Ulang}

Religiusitas merupakan aspek yang sudah melekat dalam diri pribadi tiaptiap individu. Religiusitas digambarkan sebagai petunjuk bagaimana cara menjalankan hidup dengan benar sesuai dengan aturan agama yang berlaku untuk mencapai kebahagiaan hidup didunia dan diakhirat. Religiusitas terdapat dalam berbagai aspek kehidupan tak terkecuali pada aspek sosial dan ekonomi, salah satunya pada saat memilih mengkonsumsi makanan dan minuman, yakni terdapat aturan-aturan mengenai makanan dan minuman yang diperbolehkan dikonsumsi dan yang tidak. Religiusitas adalah pertimbangan utama yang menyebabkan terjadinya keputusan pembelian ulang oleh konsumen, salah satunya dalam membeli ulang makanan yang halal (Golnaz, 2009).

Golnaz (2009) mengatakan religiusitas adalah faktor utama yang mempengaruhi seseorang konsumen muslim dalam menentukan makanan yang ingin mereka konsumsi. Pendapat sama juga dikemukakan oleh Jusmaliani dan Hanny Nasution (2008), mereka menjelaskan bahwa tindakan pembelian ulang tidak hanya sekedar mempertimbangkan faktor harga, manfaat, dan fungsi saja, akan tetapi faktor religiusitas juga ikut dipertimbangkan. Kemudian diperkuat oleh penelitian Abd Rahman et al, (2015) menjelaskan bahwa religiusitas berpengaruh terhadap minat beli ulang produk kosmetik halal. Konsumen yang percaya dan berkomitmen terhadap suatu produk maka akan dengan mudah membentuk niatnya dalam melakukan pembelian dan berkecenderungan akan mempersering melakukan pembelian produk tertentu.

$\mathrm{H}_{1}$ : Religiusitas berpengaruh terhadap minat beli ulang.

\section{Pengaruh Reputasi Merek Terhadap Minat Beli Ulang}

Dalam pemasaran lebih lanjut telah dibuktikan bahwa kesadaran merek dan reputasi suatu merek akan mempengaruhi keputusan konsumen untuk melakukan pembelian ulang. Reputasi yang baik dari sebuah perusahaan akan mempengaruhi pelanggan untuk kembali memesan atau mengkonsumsinya lagi, hal ini menunjukkan bentuk loyalitas pelanggan terhadap produk 
yang ditawarkan. Sebaliknya apabila reputasi yang dibentuk dari suatu perusahaan buruk akan membuat pelanggan enggan untuk melakukan pembelian ulang.

Dengan pembelian yang berulang kali terhadap satu merek mengindikasikan bahwa merek tersebut dirasa sangat memuaskan, maka kemungkinan besar konsumen akan menunjukkan satu proses keputusasn pembelian yang rutin, yang dalam tahap-tahap pembelian selanjutnya akan terstruktur dengan baik, sehingga mendorong pengambilan keputusan pembelian. Suatu merek diyakini memiliki nilai (value) karena dapat mempengaruhi pembelian ulang. Merek yang memiliki value dapat menujukkan tanda akan superioritas produk tersebut kepada konsumen, sehingga akan mengarah pada timbulnya pembelian ulang. Apabila suatu perusahaan dapat memenuhi kebutuhan dan keinginan konsumen maka perusahaan tersebut akan mendapat reputasi baik dimata konsumen.

Dalam penelitian sebelumnya yang dilakukan oleh Hidayati (2013) menunjukkan bahwa reputasi merek berpengaruh tehadap minat beli ulang. Kemudian diperkuat oleh penelitian Tariq et al (2013) yang menjelaskan bahwa terdapat pengaruh antara reputasi merek dengan minat beli ulang. Kusnandar (2015) mengemukakan reputasi merek berpengaruh terhadap minat beli ulang. Dengan demikian jika suatu produk memiliki reputasi yang baik, maka akan meningkatkan minat pembelian ulang. Reputasi merek dimata konsumen dinilai dari kualitas maupun differensiasi produknya, sehingga konsumen bisa membedakan produk tersebut dengan produk pesaing.

$\mathrm{H}_{2}$ : Reputasi merek berpengaruh terhadap minat beli ulang.

\section{Pengaruh Religiusitas Terhadap Sikap Konsumen}

Agama menganjurkan agar tiap-tiap individu mengikuti gaya hidup tertentu yang didasarkan pada kepercayaan yang diyakininya, termasuk kebiasaan dalam berpakaian, pola mengkonsumsi makanan dan minuman dan juga dalam urusan ekonomi. Religiusitas mempengaruhi seluruh aspek kehidupan seseorang termasuk dalam pemilihan mengkonsumsi suatu produk, salah satunya tentang anjuran seseorang muslim mengkonsumsi makanan dan minuman yang halal untuk dikonsumsi. Penelitian terdahulu yang diusung oleh Rochmanto (2014) menyatakan religiusitas berpengaruh terhadap sikap konsumen. Seseorang yang sejak kecil dibekali dengan ilmu agama akan menghindari perbuatan yang dilarang agama, hal ini mengindikasikan bahwa agama merupakan pondasi yang berpengaruh cukup kuat dalam mempengaruhi seseorang untuk melakukan sesuatu. Kemudian Mokhlis (2006) menyatakan bahwa perilaku pembelian seorang muslim condong kepada budaya, norma, sikap dan nilai-nilai yang dipengaruhi oleh agama. Sependapat dengan pendapat diatas Khraim (2010) juga mengatakan gaya hidup individu tergantung pada tingkat religiusitas, tingkat religiusitas menjadi kunci penentu sikap dan perilaku konsumen. Apabila sikap seseorang itu baik, maka gaya hidup yang ditunjukan juga ikut baik. Kemudian diperkuat oleh pendapat Abd Rahman (2015) menyatakan bahwa ada pengaruh antara religiusitas dan sikap konsumen terhadap produk kosmetik halal.

$\mathrm{H}_{3}$ : Religiusitas berpengaruh terhadap sikap konsumen

\section{Pengaruh Reputasi Merek Terhadap Sikap Konsumen}

Sikap konsumen adalah penilaian secara menyeluruh oleh konsumen akan suatu merek tertentu. Pada penelitian sebelumnya yang dilakukan oleh Chaundhuri (1999) mengemukakan bahwa terdapat pengaruh antara reputasi merek dengan sikap konsumen, dalam model reputasi merek diduga terjadi peningkatan pangsa pasar yang signifikan ketika sikap konsumen semakin tinggi. Selanjutnya Aaker dan Jacobson (2001) mengatakan 


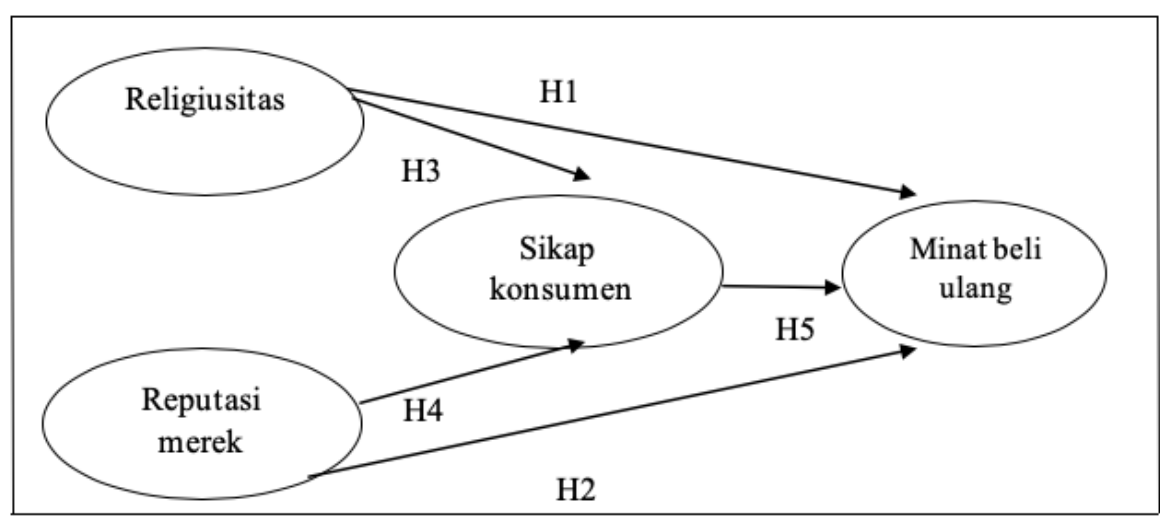

\section{Gambar 1 \\ Kerangka Pemikiran Teoritis}

reputasi merek berpengaruh terhadap sikap konsumen, sikap konsumen dapat digunakan sebagai alat untuk memprediksi kinerja bisnis dimasa yang akan datang. Sikap konsumen terhadap merek juga dapat dipengaruhi oleh kesan yang diusung oleh merek yang bersangkutan (Ruth Hilliar dan Alpert, 2002). Berdasarkan uraian diatas maka peneliti merumuskan hipotesis sebagai berikut :

$\mathrm{H}_{4}$ : Reputasi merek berpengaruh terhadap sikap konsumen.

\section{Pengaruh Sikap Konsumen Terhadap Minat Beli Ulang}

Sikap (attitude) adalah penilaian menyeluruh terhadap suatu hal yang merefleksikan perasaaan suka dan tidaknya seseorang. Sikap seorang muslim menunjukan penilaian secara menyeluruh terhadap suatu hal yang sesuai dengan norma-norma yang ada didalam agamanya. Sikap masing-masing individu akan berbeda tergantung pada besar kecilnya stimulus yang mempengaruhinya.

Penelitan terdahulu yang diusung oleh Alam dan Sayuti (2011) dalam Rochmanto (2014) menjelaskan terdapat pengaruh antara sikap konsumen terhadap minat beli ulang.

\section{Kerangka Pemikiran Teoritis}

Berdasarkan uraian diatas maka gambar kerangka pikir pada penelitian ini ada pada gambar 1.

\section{METODE PENELITIAN}

Populasi dalam penelitian ini adalah konsumen restoran KFC di kota Semarang.

Berdasarkan rumus Slovin, sampel yang dapat diambil dari populasi yang benar sebanyak 96 orang. Kemudian dibulatkan sebesar 100 responden agar penelitian lebih valid.

\section{Metode Pengumpulan Data}

Untuk memperoleh data dan informasi yang sesuai dengan objek penelitian ini, penulis melakukan kegiatan metode pengumpulan data dengan menggunakan kuesioner (angket). Kuesioner merupakan sejumlah pertanyaan tertulis yang digunakan untuk memperoleh informasi dari responden dalam arti laporan tentang pribadinya, atau hal-hal yang ia ketahui.

\section{Alat Analisis Data}

Untuk mengukur pengaruh variabel religiusitas dan reputasi merek terhadap minat beli ulang melalui sikap konsumen digunakan software SPSS.

\section{HASIL DAN PEMBAHASAN Uji Validitas}

Untuk menguji valid dan tidaknya pertanyaan yang akan diajukan dengan 


\begin{tabular}{lcccc}
$\begin{array}{l}\text { Tabel 1 } \\
\text { Hasil Pengujian Validitas }\end{array}$ & & & & \\
\multicolumn{1}{c}{ Variabel } & Indikator & r hitung & r tabel & Ket \\
\hline Religiusitas & X1.1 & 0.494 & 0.195 & Valid \\
& X1.2 & 0.606 & 0.195 & Valid \\
& X1.3 & 0.603 & 0.195 & Valid \\
& X1.4 & 0.661 & 0.195 & Valid \\
Reputasi Merek & X1.5 & 0.565 & 0.195 & Valid \\
& X2.1 & 0.580 & 0.195 & Valid \\
& X2.2 & 0.625 & 0.195 & Valid \\
& X2.3 & 0.756 & 0.195 & Valid \\
Sikap Konsumen & X2.4 & 0.786 & 0.195 & Valid \\
& Y1.1 & 0.708 & 0.195 & Valid \\
& Y1.2 & 0.807 & 0.195 & Valid \\
Minat Beli Ulang & Y1.3 & 0.796 & 0.195 & Valid \\
& Y2.1 & 0.653 & 0.195 & Valid \\
& Y2.2 & 0.731 & 0.195 & Valid \\
& Y2.3 & 0.765 & 0.195 & Valid \\
Y.647 & & & & \\
Valid & & & & \\
\hline
\end{tabular}

Sumber : Data primer yang diolah, 2018

Tabel 2

Hasil Pengujian Reliabilitas

\begin{tabular}{lccc}
\hline \multicolumn{1}{c}{ Variabel } & Alpha & Kondisi & Keterangan \\
\hline Religiusitas & 0.725 & $>0.60$ & Reliabel \\
Reputasi merek & 0.635 & $>0.60$ & Reliabel \\
Sikap konsumen & 0.658 & $>0.60$ & Reliabel \\
Minat beli ulang & 0.650 & $>0.60$ & Reliabel \\
\hline
\end{tabular}

Sumber : Data primer yang diolah, 2018

membandingkan nilai $r$ hitung dengan $r$ tabel. Apabila $r$ hitung $>r$ tabel, maka pertanyaan valid, sebaliknya apabila $r$ hitung $<r$ tabel, maka pertanyaan tidak valid. Pengujian validitas dalam penelitian ini hasilnya ada pada tabel 1.

Tabel 1 menunjukkan bahwa semua indikator yang digunakan untuk mengukur variabel - variabel penelitian ini mempunyai nilai $r$ hitung yang lebih besar dari 0.195. Dengan demikian semua indikator tersebut adalah valid.

\section{Uji Reliabilitas}

Uji reliabilitas dimaksudkan untuk mendapatkan data yang reliabel. Selanjutnya uji reliabilitas pada pengujian ini menggunakan Cronbach Alpha (a), dimana 
Tabel 3

Pengujian Multikolinieritas

Coefficients $^{a}$

\begin{tabular}{lcc}
\hline \multirow{2}{*}{ Model } & \multicolumn{2}{c}{ Collinearity Statistics } \\
\cline { 2 - 3 } (Constant) & & VIF \\
Religiusitas &, 666 & \\
Reputasi Merk &, 600 & 1,501 \\
Sikap Konsumen &, 625 & 1,667 \\
\hline
\end{tabular}

a. Dependent Variable: Minat Beli Ulang

Sumber : Data primer yang diolah, 2018

Scatterplot

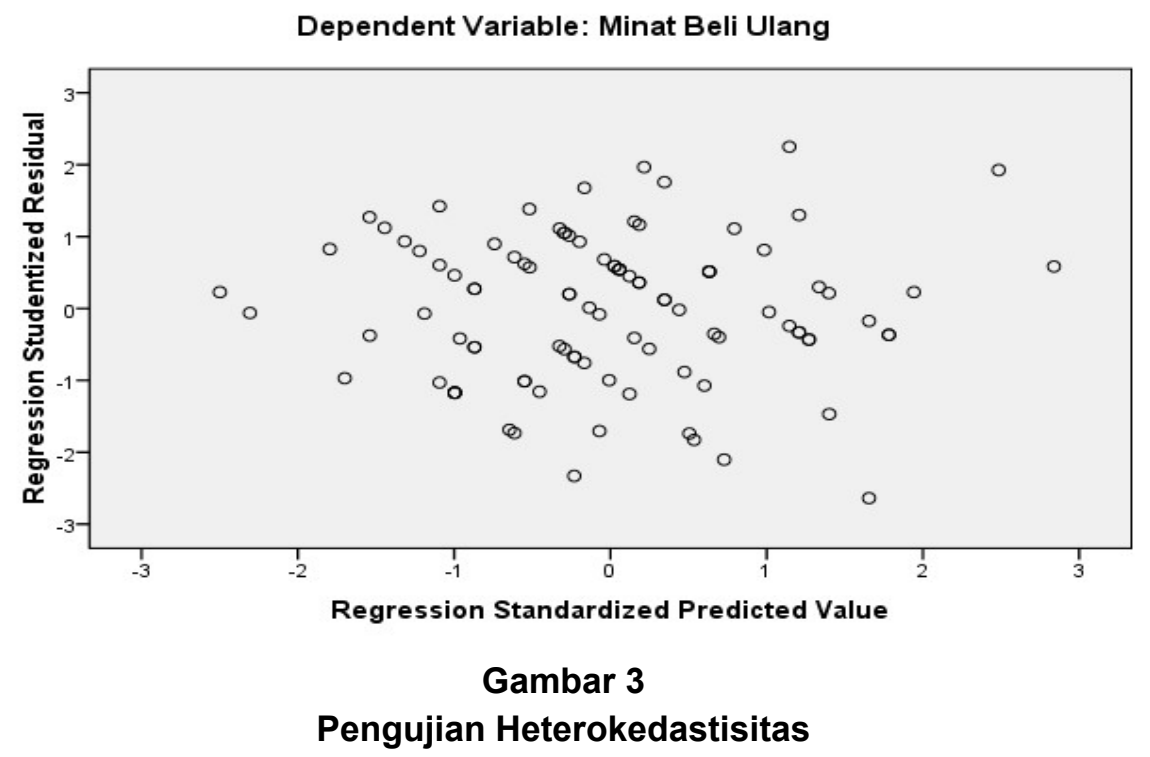

jika nilai a > 0.60 maka kuesioner dikatakan

residual error model regresi diatas sudah handal atau reliabel (Imam Ghozali, 2011). menunjukkan adanya pola grafik yang Pengolahan data menggunakan software SPSS yang hasilnya disajikan pada tabel 2 . normal, karena membentuk satu garis lurus diagonal, dan adanya sebaran titik yang

Hasil uji reliabilitas tersebut menunjukkan bahwa semua variabel mempunyai koefisien Alpha yang cukup besar yaitu diatas 0.60 , maka dapat dikatakan semua konsep pengukur masing-masing variabel dari kuesioner adalah reliabel atau handal.

\section{Uji Asumsi Klasik}

\section{Uji Normalitas}

Berdasarkan hasil analisis regresi linier dengan grafik normal P-P Plot terhadap berada tidak jauh dari garis diagonal.

\section{Uji Multikolinieritas}

Hasil pengujian menunjukkan bahwa nilai VIF dari semua variabel bebas memiliki nilai $<10$. Hal ini berarti bahwa variabel - variabel penelitian tidak menunjukkan adanya gejala multikolonieritas dalam model regresi.

\section{Uji Heterokedastisitas}

Hasil output pengolahan SPSS terlihat

EKOBIS Vol. 20, No.2, Juli 2019 : 48 - 61 
grafik scatterplot menunjukkan titik-titik menyebar secara acak serta tersebar diatas maupun dibawah angka nol pada sumbu Y. Dapat disimpulkan bahwa model regresi yang dipakai tidak terjadi heterokedastisitas.

\section{Analisis Regresi Linier Berganda} Regresi Berganda Pengaruh Religiusitas dan Reputasi Merek terhadap

\section{Sikap Konsumen}

Berdasarkan output SPSS, maka persamaan regresi yang mencerminkan variabel-variabel dalam penelitian ini dapat ditulis sebagai berikut :

$$
\mathrm{Y} 1=0.274 \mathrm{X}_{1}+0.423 \mathrm{X}_{2}+\mathrm{e} 1
$$

Hasil persamaan regresi berganda tersebut memberikan pengertian bahwa : 1 . Koefisien regresi religiusitas menunjukkan nilai sebesar 0.274 , artinya jika religiusitas semakin baik maka sikap konsumen juga akan meningkat. 2. Koefisien regresi reputasi merek menunjukkan nilai sebesar 0.423 , artinya jika reputasi merek semakin baik maka sikap konsumen juga akan meningkat.

Nilai Adjusted $R$ Square yaitu sebesar 0.363 , yang menunjukkan bahwa variasi dari sikap konsumen dapat dijelaskan oleh variabel indepeden antara religiusitas dan reputasi merek sebesar $36.3 \%$, sedangkan sisanya $63.7 \%$ dijelaskan oleh variabel lain diluar model penelitian.

\section{Regresi Berganda Pengaruh Religiusitas Reputasi Merek dan Sikap Konsumen terhadap Minat Beli Ulang}

Berdasarkan perhitungan regresi berganda antara religiusitas, reputasi merek dan sikap konsumen terhadap minat beli ulang dalam proses penghitungannya diperoleh hasil sebagai berikut :

Berdasarkan hasil uji SPSS diatas, maka persamaan regresi yang mencerminkan variabel-variabel dalam penelitian ini dapat ditulis sebagai berikut :

$$
Y 2=0.163 X_{1}+0.590 X_{2}+0.202 Y_{1}+e 2
$$

Hasil persamaan regresi berganda tersebut memberikan pengertian bahwa : 1 . Koefisien regresi religiusitas menunjukkan nilai sebesar 0.163 , artinya jika religiusitas semakin baik maka minat beli ulang juga akan meningkat. 2. Koefisien regresi reputasi merek menunjukkan nilai sebesar 0.590 , artinya jika reputasi merek semakin baik maka minat beli ulang akan meningkat. 3. Koefisien regresi sikap konsumen menunjukkan nilai sebesar 0.202 , artinya jika sikap konsumen semakin baik maka minat beli ulang akan meningkat.

Nilai Adjusted $R$ Square yaitu sebesar 0.674 yang menunjukkan bahwa variasi minat beli ulang dapat dijelaskan oleh variabel religiusitas, reputasi merek dan sikap konsumen sebesar $67.4 \%$, sedangkan sisanya $32.6 \%$ dijelaskan oleh variabel lain yang tidak diteliti dalam penelitian. Pengujian Hipotesis Parameter Individual (Uji t)

\section{Pengaruh Religiusitas Terhadap Minat Beli Ulang}

Dari hasil perhitungan pada tabel 6 diperoleh nilai t hitung sebesar 2.314 dan siginifikan pada 0.023 artinya sig $t<0.05$ hal ini menandakan bahwa religiusitas berpengaruh positif dan signifikan terhadap minat beli ulang.

\section{Pengaruh Reputasi Merek Terhadap Minat Beli Ulang}

Dari hasil perhitungan pada tabel 6 diperoleh $t$ hitung sebesar 7.966 dan signifikan pada 0.000 , artinya sig $t<0.05$ hal ini menandakan bahwa reputasi merek berpengaruh positif dan signifikan terhadap minat beli ulang.

\section{Pengaruh Religiusitas Terhadap Sikap Konsumen}

Dari hasil perhitungan pada tabel 4 diperoleh $t$ hitung sebesar 2.902 dan 
signifikan pada 0.005 , artinya sig $t<0.05$, hal ini menandakan bahwa religiusitas berpengaruh positif dan signifikan terhadap sikap konsumen.

\section{Pengaruh Reputasi Merek Terhadap Sikap Konsumen}

Dari hasil perhitungan pada tabel 4 diperoleh $t$ hitung sebesar 4.487 dan siginifikan pada 0.000 , artinya sig $t<0.05$, hal ini menandakan bahwa reputasi merek berpengaruh positif dan signifikan terhadap sikap konsumen.

\section{Pengaruh Sikap Konsumen Terhadap Minat Beli Ulang}

Dari hasil perhitungan pada tabel 6 diperoleh $t$ hitung sebesar 2.785 dan signifikan pada 0.006 , artinya sig $t<0.05$, hal ini menandakan. bahwa sikap konsumen berpengaruh positif dan signifikan terhadap minat beli ulang.

\section{Uji Sobel Test}

Berdasarkan hasil uji sobel test diketahui pengaruh religiusitas terhadap minat beli ulang melalui sikap konsumen menghasilkan nilai probability sebesar 0.0551 , karena nilai probability > 0.05 maka Ha diterima, artinya sikap konsumen tidak dapat memediasi pengaruh religiusitas terhadap minat beli ulang. Kemudian pengaruh reputasi merek terhadap minat beli ulang melalui sikap konsumen menghasilkan nilai probability sebesar 0.0302 , karena nilai probability < 0.05 maka Ho ditolak, artinya sikap konsumen dapat memediasi pengaruh reputasi merek terhadap minat beli ulang.

\section{Pembahasan \\ Pengaruh Religiusitas Terhadap Minat Beli Ulang}

Religiusitas berpengaruh positif dan signifikan terhadap minat beli ulang, artinya apabila religiusitas yang dimiliki konsumen semakin baik, yaitu konsumen yakin bahwa produk KFC telah memenuhi syarat sebagai produk halal, konsumen merasa nyaman jika membeli produk KFC, konsumen mengetahui bahwa KFC sudah mendapatkan sertifikat halal dari Majelis Ulama Indonesia (MUI), konsumen membeli produk halal sebagai bentuk muamalah sesuai perintah agama, konsumen yakin bahwa pemotongan ayam di KFC sudah sesuai dengan syariat agama Islam, maka minat untuk membeli ulang produk KFC semakin meningkat.

Religiusitas adalah sejauh mana seseorang memiliki komitmen untuk mempelajari dan mengamalkan nilai-nilai dan norma-norma yang berlaku didalam agama Islam. Golnaz (2009) mengatakan religiusitas adalah faktor utama yang mempengaruhi seseorang konsumen muslim dalam menentukan makanan yang ingin mereka konsumsi. Konsumen yang percaya dan berkomitmen terhadap suatu produk akan dengan mudah membentuk niatnya dalam melakukan pembelian dan berkecenderungan akan mempersering melakukan pembelian ulang produk tertentu. Teori tersebut mendukung penelitian dari Abd Rahman et al (2015) yang menyatakan bahwa religiusitas memiliki pengaruh terhadap minat beli ulang suatu produk. Pendapat sama juga dikemukakan oleh Jusmaliani dan Hanny Nasution (2008), mereka menjelaskan bahwa tindakan pembelian ulang tidak hanya sekedar mempertimbangkan faktor harga, manfaat, dan fungsi saja, akan tetapi faktor religiusitas juga ikut dipertimbangkan.

\section{Pengaruh Reputasi Merek Terhadap Minat Beli Ulang}

Reputasi merek berpengaruh positif dan signifikan terhadap minat beli ulang, artinya apabila reputasi merek KFC semakin baik, yaitu KFC memiliki reputasi baik dimata konsumen, KFC memiliki pelayanan yang cepat dan tanggap, KFC selalu berinovasi dengan produk maupun pelayanannya, KFC melayani semua segmen, KFC selalu mengerti kebutuhan dan keinginan konsumen, KFC memiliki tempat yang bersih indah dan nyaman, KFC menawarkan 
harga yang cukup terjangkau, maka minat konsumen untuk membeli ulang produk KFC semakin meningkat.

Reputasi merupakan kumpulan dari sekian banyak opini (pendapat) seseorang menganai objek tertentu. Reputasi merek mengacu pada opini atau pendapat orang tentang suatu merek bahwa merek tersebut "good and reliable". Semakin baik reputasi sebuah merek berarti semakin banyak orang yang menilai bahwa merek tersebut "good and reliable". Dalam penelitian ini reputasi restoran KFC sangat baik, mulai dari menu yang disajikan beragam variasi, tempatnya nyaman, harganya pun cukup terjangkau bagi semua kalangan. sehingga konsumen tertarik untuk melakukan pembelian ulang pada restoran KFC.

Teori ini mendukung penelitian dari Hidayati (2013) yang menunjukkan bahwa reputasi merek berpengaruh tehadap minat beli ulang. Hal sama dikemukakan oleh Narjono (2012) yang menyatakan bahwa reputasi yang dikelola dengan baik akan menghasilkan konsekuensi yang positif, karena konsumen senantiasa mempertimbangkan reputasi merek tertentu untuk membeli ulang suatu produk. Tariq et al (2013) juga mengemukakan bahwa terdapat pengaruh antara reputasi merek dengan minat beli ulang.

\section{Pengaruh Religiusitas Terhadap Sikap Konsumen}

Religiusitas berpengaruh positif dan signifikan terhadap sikap konsumen, artinya apabila religiusitas yang ditunjukan oleh konsumen semakin baik, yaitu konsumen yakin bahwa produk-produk yang dijual di KFC telah memenuhi syarat sah sebagai produk halal, konsumen merasa nyaman dan tenang jika membeli produk KFC karena sesuai dengan keyakinan, konsumen membeli produk halal sebagai salah satu bentuk muamalah sesuai perintah agama, maka sikap konsumen akan semakin meningkat.

Religiusitas mempengaruhi seluruh aspek kehidupan seseorang, termasuk dalam mengkonsumsi produk, yakni berhubungan dengan pembatasan makanan yang boleh dikonsumsi dan yang tidak. Saat ini konsumen muslim semakin memperhatikan status halal produk yang mereka konsumsi, baik itu makanan, maupun maupun kebutuhan lainnya. Konsumen muslim mengatakan saat ini halal bukan lagi gaya hidup, tetapi adalah sebuah kebutuhan semua orang. Hal ini sesuai dengan hasil penelitian Golnaz (2009) bahwa religiusitas merupakan faktor utama yang mempengaruhi konsumen muslim untuk memilih produk yang akan mereka konsumsi dengan tepat (halal). Sheik dan Thomas dalam Rochmanto (2014) menyatakan religiusitas berpengaruh terhadap sikap seseorang. Kemudian diperkuat oleh pendapat Abd Rahman (2015) menyatakan bahwa ada pengaruh antara religiusitas dan sikap konsumen.

\section{Pengaruh Reputasi Merek Terhadap Sikap Konsumen}

Reputasi merek berpengaruh positif dan signifikan terhadap sikap konsumen, artinya apabila reputasi KFC semakin baik, yaitu restoran KFC dikenal luas oleh masyarakat, KFC mengedepankan kepuasan pelanggan, KFC memiliki layanan yang tepat waktu dan memadai, restoran KFC memiliki lingkungan yang bersih, indah dan nyaman, maka sikap konsumen juga akan semakin meningkat.

Aaker dan Jacobson (2001) mengatakan reputasi merek berpengaruh terhadap sikap konsumen, sikap konsumen terhadap suatu merek juga dapat digunakan sebagai alat untuk memprediksi kinerja bisnis dimasa yang akan datang, artinya perusahaan dapat memprediksi apa yang diinginkan konsumen dimasa mendatang dengan melihat sikap konsumen dimasa sekarang, misalnya waktu zaman dahulu tujuan konsumen datang ke restoran KFC hanya untuk sekedar melepas rasa lapar dan dahaga saja, namun zaman sekarang seseorang ke restoran KFC bukan lagi untuk sekedar melepas rasa lapar dan 
dahaga saja, akan tetapi untuk berwisata kuliner, foto-foto, melepas penat, update di sosial media, agenda meeting dengan klien, mengerjakan tugas sekolah atau kuliah, hangout sama temen, acara party atau ulang tahun dan lain sebagainya. Sehingga saat ini tujuan seseorang pergi ke restoran KFC menjadi bergeser. Hal itu tentunya akan meningkatkan sikap konsumen terhadap produk KFC.

\section{Pengaruh Sikap Konsumen Terhadap Minat Beli Ulang}

Sikap konsumen berpengaruh positif dan signifikan terhadap minat beli ulang, artinya apabila sikap konsumen yang tunjukan semakin baik, yaitu konsumen percaya pada produk KFC, konsumen merasa puas dengan produk KFC dan akan kembali untuk mencobanya, konsumen memilih produk KFC karena kualitas dan rasanya, maka minat konsumen untuk melakukan pembelian ulang produk KFC akan meningkat.

Sikap (attitude) adalah penilaian menyeluruh yang merefleksikan perasaaan suka dan tidaknya seseorang terhadap suatu objek atau peristiwa. Sikap seorang muslim menunjukan penilaian secara menyeluruh terhadap sesuatu sesuai dengan normanorma yang ada didalam agamanya. Sikap masing-masing individu akan berbeda tergantung pada besar kecilnya stimulus yang mempengaruhinya. Apabila seorang mempunyai sikap positif terhadap suatu produk maka orang tersebut akan berupaya untuk mendapatkan produk yang diinginkannya sehingga sulit untuk beralih ke produk lain. Pada penelitian ini sikap konsumen khususnya dalam membeli ulang produk KFC dipengaruhi oleh beberapa faktor salah satunya persepsi, yaitu konsumen mempersepsikan KFC sebagai produk halal, konsumen yakin bahwa daging yang dijual di KFC adalah daging ayam, bukan daging hewan lainnya yang diharamkan oleh agama Islam. Walaupun proses pemotongannya menggunakan mesin tetapi prosedurnya tetap sama dengan aturan agama Islam. Sehingga konsumen muslim lebih memilih makan di KFC ketika mereka ingin makan direstoran cepat saji. Dengan adanya sikap konsumen tersebut maka dapat menciptakan minat pembelian ulang terhadap produk KFC.

Hasil ini sesuai dengan hasil penelitian Karina et al (2017) menunjukkan bahwa sikap konsumen berpengaruh signifikan terhadap minat beli ulang produk kosmetik. Alam dan Sayuti (2011) dalam Rochmanto (2014) juga menjelaskan terdapat pengaruh positif dan signifikan antara sikap konsumen terhadap minat beli ulang suatu produk makanan halal.

\section{SIMPULAN}

Berdasarkan hasil penelitian yang telah dilakukan maka dapat diperoleh kesimpulan bahwa religiusitas terbukti berpengaruh positif dan signifikan terhadap minat beli ulang, artinya apabila religiusitas yang dimiliki konsumen semakin baik, yaitu konsumen yakin bahwa produk KFC telah memenuhi syarat sebagai produk halal, konsumen merasa nyaman jika membeli produk KFC, konsumen mengetahui bahwa KFC sudah mendapatkan sertifikat halal dari Majelis Ulama Indonesia (MUI), konsumen membeli produk KFC sebagai bentuk muamalah sesuai perintah agama, konsumen yakin bahwa pemotongan ayam di KFC sudah sesuai dengan syariat agama Islam, maka minat untuk membeli ulang produk KFC juga semakin meningkat.

Reputasi merek berpengaruh positif dan signifikan terhadap minat beli ulang, artinya apabila reputasi merek yang dimiliki oleh KFC semakin baik, yaitu KFC dikenal luas oleh masyarakat, KFC memiliki pelayanan yang cepat dan tanggap, KFC selalu berinovasi dengan menu-menunya, KFC melayani semua segmen, KFC restoran yang memenuhi kebutuhan dan keinginan konsumen, KFC memiliki tempat yang bersih, indah dan nyaman, KFC menawarkan harga yang cukup terjangkau, maka minat 
konsumen untuk melakukan pembelian ulang produk KFC semakin meningkat.

Religiusitas berpengaruh positif dan signifikan terhadap sikap konsumen, artinya apabila religiusitas yang ditunjukan oleh konsumen semakin baik, maka sikap konsumen terhadap produk KFC akan semakin meningkat. Reputasi merek terbukti berpengaruh signifikan terhadap sikap konsumen, artinya semakin baik reputasi KFC, maka sikap konsumen tehadap produk KFC juga akan semakin meningkat.

Sikap konsumen berpengaruh positif dan signifikan terhadap minat beli ulang, artinya apabila sikap konsumen yang terdiri dari tiga indikator yaitu konsumen percaya pada produk KFC, konsumen merasa puas terhadap produk KFC dan akan kembali untuk membelinya, konsumen memilih produk KFC karena kualitas dan rasanya, meningkat maka minat konsumen untuk membeli ulang produk KFC juga akan semakin meningkat.

\section{Saran}

Perlu adanya upaya peningkatan variabel religiusitas terutama pada pernyataan "saya membeli produk KFC sebagai bentuk mualamah sesuai perintah agama" karena masih terdapat sebagian kecil responden yang belum mampu menerapkan sikap tersebut.

Berdasarkan hasil jawaban responden menunjukkan bahwa pernyataan "saya selalu merasa puas akan produk KFC dan akan kembali untuk membelinya" mendapatkan jawaban terendah dalam mengukur variabel sikap konsumen, sehingga KFC harus lebih meningkatkan lagi kualitas layanan yang diberikan kepada konsumen, selalu berinovasi dalam setiap menu-menu yang ditawarkan agar konsumen merasa puas.

Berdasarkan hasil jawaban responden menunjukkan bahwa pernyataan "saya lebih memilih restoran KFC dibanding restoran lainnya" mendapatkan jawaban terendah dalam mengukur variabel minat beli ulang, sehingga KFC harus selalu melakukan evaluasi secara rutin agar KFC mengenali kebutuhan dan keinginan konsumen seperti apa, agar dapat meresponnya dengan cepat.

\section{Keterbatasan Penelitian}

Menggunakan objek kurang luas, yaitu hanya pada KFC di kota Semarang saja, dengan jumlah kuesioner yang disebar sebanyak 100 responden. Tentu hasilnya belum bisa digeneralisasikan bagi penelitian dengan objek yang sama dilain tempat.

Variabel penelitian ini hanya terbatas pada 4 variabel saja yaitu religiusitas reputasi merek, sikap konsumen dan minat beli ulang, sehingga kurang memenuhi kondisi sesungguhnya di lapangan.

Teknik pengumpulan data yang dipakai dalam penelitian ini hanya menggunakan kuesioner, sehingga kesimpulan yang dapat diambil hanya berdasarkan pada data yang dikumpulkan melalu kuesioner tersebut.

\section{Agenda Penelitian Mendatang}

Pada penelitian selanjutnya sebaiknya perlu menambahkan variabel penelitian yang dirasa dapat memperkaya hasil penelitian sebelumnya.

Pada penelitian selanjutnya sebaiknya teknik pengumpulan data perlu ditambah dengan teknik wawancara

Untuk penelitian mendatang disarankan memperluas populasi atau bahkan mengambil populasi yang berbeda. Sampelnya ditingkatkan diusahakan jumlahnya lebih besar dari sampel sebelumnya.

Untuk penelitian mendatang disarankan agar menggunakan atau menambahkan objek penelitian selain restoran KFC, seperti McDonald, Solaria, Pizza Hut, Gramedia, Bank Syariah atau Konvensional. 


\section{DAFTAR PUSTAKA}

Aaker, David. A., Jacobson, Robert, 2001. The value relevance of brand attitude in hightechnology markets. Journal of Marketing Research. Vol. XXXVIII, $485 \square 493$

Abd Rahman, et al. 2015. Consumers and Halal Cosmetic Products Knowledge, Religiosity, Attitude and Intention. Journal of Islamic Marketing, 6 (1), 148-163

Ajzen, I. 1991. The Theory Of Planned Behavior, Organizational Behavior And Human Decision Processes, Vol. 50, No. 2, Pp.179-211

Alam, S. S. \& Sayuti, N. M. 2011.Applying The Theory Of Planned Behavior (TPB) In Halal Food Purchasing. Intenational Journal Of Commerce And Management, Vol. 21 No.1, pp. 8-120

Chi, Hsin Kuang, Huery Ren Yeh, Ya Ting Yang. 2009. The Impact of Brand Awareness on Customer Purchase Intention :The Mediating Effect Of Received Quality and Brand Loyalty. The Journal Of Internasional Management Studies. Vol 4 No 1

Engel, J.F Blacwell. Roger D. \& Paul W. Winiard. 1997. Perilaku Konsumen. Alih Bahasa: Budiyanto. F.X. Jilid II, Binapura Aksara. Jakarta

Fakhrurizky. Nst. Muhammad., Hanifa Yasin, 2014. Jurnal Manajemen \& Bisnis Vol. 14 No.02, ISSN 1693-7619

Fishbein and Icek Ajzen. 2004. Attitudes, Personality and Behavior. New York: Open University Press

Ghozali, Imam,. 2011. Aplikasi Analisis Multivariate Dengan program SPSS. Semarang: Badan Penerbit Universitas Diponegoro

Golnaz., R., Zaenalabidin , M., Nasir,. S \& Eddie Chiew, F. C 2010. Non-Muslim Awareness of Halal Principles and Related Food Products in Malaysia.

Internasional food research journal, Vol. 17,PP.667-674

Hardjana, AM, 2005. Religiusitas, Agama dan Spiritual. Jakarta

Hanny Nasution. 2008. Religiosity Aspect in Consumer Behaviour: Determinants of Halal Meat Consumption. Centre for Economic and Development Studies, Indonesian Institute of Sciences Department of Marketing, Monash University Jurnal NCMR

Huang, C. C, et. al. 2014. The Relationship Among Brand Equity, Customer Satisfaction and Brand Resonance to Repurchase Intention of Cultural and Creative Industries in Taiwan, IJOI

Johnson, B.R., Jang, S.J., Larson D.B., \& Li, S.D 2001. Does Adolescent

Religious Commitment Matter? A Reexamination of The Effects Of Religiosity On Delinquency, Journal of Research in Crime and Delinquency, Vol. 38 (1), 22-43

Jusmaliani \& Hanny Nasution. 2008. Religiosity Aspect in Consumer Behaviour: Determinants of Halal Meat Consumption. Centre for Economic and

Development Studies, Indonesian Institute of Sciences Department of

Marketing, Monash University Jurnal NCMR

Kertajaya, Hermawan, dan Sula. 2006. Syariah Marketing. Mizan : Bandung

Khraim H. 2010. Measuring Religiosity in Consumer Research from Islamic Perspective. International Journal of Marketing Studies, Vol. 2 (2), 166179

Kotler Philip, dan Kevin Lane Keller, 2005. Manajemen Pemasaran Jilid 1. Cetakan kedua. PT.Indeks Kelompok Gramedia, Jakarta

Kotler, Philip dan Gary Amstrong, 2004. Manajemen Pemasaran jilid 1 edisi kesebelas. : PT. Indeks Indonesia, Jakarta

Kusnandar. 2015. Pengaruh Citra Merek dan Kesadaran Label Halal Produk Kosmetik La Tulipe terhadap Minat Konsumen untuk Membeli Ulang di Kota Banyuwangi. Skripsi. 
Universitas Jember

Lada, S., Tanakinjal, G. H. \& Amin, H 2009. Predicting Intention to Choose Halal Products Using Theory of Reasoned Action, Internasional Journal of Islamic And Middle Eastern Finance And Management, Vol. 2 No.1 Pp 66-67

Lovidya, Hilmi. 2012. Analisis Faktor - Faktor Yang Mempengaruhi Niat Mengkonsumsi Daging Halal. Skripsi. Universitas Indonesia, Jakarta

Makrufah. Ismi Aziz. 2016. Pengaruh Citra Merek dan Label Halal Terhadap Keputusan Pembelian Kosmetik, Skripsi. Universitas Islam Negeri Surakarta, Surakarta

Metawa, S. A. and Almossawi, M. 1998. Banking Behavior Of Islamic Bank Customers: Perspectives and Implications. International Journal of Bank Marketing, Vol. 16 (7), 299313

Narjono, Arijo Isnoer. 2012. Atribut Produk sebagi Dasar Pembelian Susu (Studi pada Swalayan Singosari Kabupaten Malang). Ekonomika Jurnal Ekonomi. Vol. 5. No. 1

Reitsma, Jan, dkk. 2006. Dimension of Individual Religiosity and Charity Cross National Effect Differences in European Countries. on Review of Religious Reearch. Vol. 47 (4) PP: 347362

Rizan, M., Handayani, dkk. 2015. Pengaruh Citra Merekdan Kualitas Produk Terhadap Keputusan Pembelian (Studi Konsumen Indomie dan Mie Sedap). Jurnal Riset Manajemen Sains Indonesia. Vol 6 (1). 457-478

Robbins, Stephen. P 2006. Perilaku Organisasi (alih bahasa Drs. Benjamin Molan). Edisi Bahasa Indonesia, PT Intan, Sejati Klaten

Rochmanto, Bayu Al. 2014. Pengaruh Pengetahuan Produk dan Norma Religius Terhadap Sikap Konsumen Dalam Niat Mengkonsumsi Produk Makanan dan Minuman Halal, Skripsi. Universitas Diponegoro, Semarang

Ruth, Rettie., Simon Hilliar, and FrankAlpert, 2002, Pioner Brand Advantage with UK Consumers, Journal of Marketing, Vol. 36, No. 7/8, pp. 895 $\square 911$

Saiful, Hidayat. 2017. Analisis Pengaruh Religiosity, Consumer Ethnocentrism, dan Country Of Origin Terhadap Purchase Intention. Skripsi. Universitas Muhammadiyah Surakarta. Surakarta

Sangadji, Etta Memang dan Sopiah. 2013. Perilaku Konsumen. Penerbit Andi Yogyakarta

Schiffman, Leon G and Kanuk, Leslie Lazar. 2007. Consumer Behavior, Global Edition. Tenth Editon Pearson

Setiadi, Nugroho J. 2005. Perilaku Konsumen, Konsep dan Implikasi Untuk Strategi dan Penelitian Pemasaran. Penerbit : Kencana, Jakarta

Setiawati, 2015. Pengaruh Harga dan Citra Merek Terhadap Keputusan

Pembelian Televisi Samsung di Perumahan Villa Grand

TomangTangerang. Prosiding Seminar Nasional Multi Disiplin Ilmu \& Call For Papers Unisbank, Semarang

Sugiyono, 2012. Statistik Untuk Penelitian. Penerbit : Alfabeta, Bandung

Suryani, Tatik. 2008. Perilaku Konsumen: Implikasi Pada Strategi Pemasaran, Yogyakarta: Graha IImu

Sutisna, 2002. Perilaku Konsumen dan Komunikasi Pemasaran, Rosda

Swastha, Basu dan Irawan. 2008. Manajemen Pemasaran Modern, Liberty, Yogyakarta

Tariq, Muhammad Irfan. Muhammad Rafay Nawas, Muhammad Musarrat Nawas, Hashim Awais Butt. 2013. Customer Perception About Branding and Purchase Intention A Study of FMCG in an Emerging Market. Journal of Basic Applied Scientic Research

Wardhana, Reza Arief. 2012. Analisa Pengaruh Mutu Produk, Reputasi Merek dan Promosi Terhadap Minat Beli Konsumen Pada Produk Anti Karat Tuff Kote Dinol. Skripsi. 